\title{
Polyphenoloxidase activity and total phenolic content as related to browning of minimally processed 'Jonagored' apple
}

\author{
Ada MCN Rocha and Alcina MMB Morais* \\ Escola Superior de Biotecnologia, Universidade Católica Portuguesa, Rua Dr António Bernardino de Almeida, 4200-072 Porto, Portugal
}

\begin{abstract}
Phenolic content, polyphenoloxidase (PPO) activity and browning have been reported by different authors to vary in different ways, depending on cultivar, picking maturity, storage conditions, etc. Numerous authors have attempted to correlate browning results with the phenolic content and/or enzymatic activity of apples, but data published in the literature are divergent as to which of the two factors, ie the enzyme or the substrate, plays the decisive role in the overall phenomenon of enzymatic browning. The aim of this work was to follow the PPO activity and phenolic content of minimally processed apple (cv 'Jonagored') during cold storage and to establish a potential relationship with enzymatic browning. Increasing storage time of minimally processed apple seemed to result in an increase in PPO activity. No changes $(P>0.05)$ in total phenolic content were observed during storage. Colour degradation of apple cubes, as indicated by changes in colour parameters, was found to be highly correlated with PPO activity. Browning of 'Jonagored' apple cubes during storage was found to be moderately correlated with PPO activity. No correlation was found between the browning index and the total phenolic content.
\end{abstract}

Keywords: browning; Malus pumila; 'Jonagored'; polyphenoloxidase; phenols; phenolic content; storage

\section{INTRODUCTION}

The level of polyphenoloxidase (PPO; EC 1.14.18.1) activity at harvest and its variation during fruit storage have been considered important for prediction of susceptibility to browning. Contradictory data exist in the literature concerning PPO evolution during fresh storage. ${ }^{1}$ The study of different apple varieties is important, since PPO activity is cultivar-dependent. ${ }^{2}$ Compared with other varieties ('Classic Delicious', 'Golden Delicious', 'Cortland', 'RI Greening', 'McIntosh'), 'Red Delicious' always has the highest PPO activity. ${ }^{3,4}$

It is generally assumed that minimal processing operations cause disruption of compartmentalisation, allowing substrates and enzymes (oxidases) to come into contact. ${ }^{5}$ Since it is generally agreed that PPO is the enzyme mainly responsible for browning, ${ }^{6}$ an increase in PPO activity after peeling and cutting would be expected. Wounding also induces the synthesis of some enzymes involved in browning reactions or substrate biosynthesis. The contribution of other enzymes (eg peroxidase) to total browning may also be relevant. ${ }^{7}$

Phenolic compounds are secondary plant metabolites that have an important role in providing flavour and colour characteristics of fruit products. There is general agreement that the concentration of phenolic compounds is very high in young fruits and then rapidly decreases during fruit development. Studies carried out on the phenolic content of developing apples reflect this general trend. ${ }^{2,3}$ After harvest the concentration of total phenols remains essentially constant or decreases slightly, ${ }^{3,8,9}$ but individual phenolic compounds have been shown to vary in their browning rates. Chlorogenic acid has been shown to be the major phenolic compound in apple, ${ }^{8}$ decreasing rapidly during the early stage of fruit development to reach an almost steady level at maturity, while catechins have been reported to vary irregularly and to decrease. ${ }^{9}$

When cellular compartmentalisation is disrupted, phenolic compounds may be involved in both enzymatic and non-enzymatic browning reactions. In the former case the oxidation of phenolic substrates is catalysed by PPO, and the quinones formed can take part in secondary reactions, bringing about the formation of dark secondary products. ${ }^{10}$ In the latter case the common cause of darkening is attributable to interactions between phenols and heavy metals, eg iron, which yield coloured complexes. ${ }^{6}$ Enzyme inactivation and a decrease in substrate content seem to occur after bruising. ${ }^{11}$

* Correspondence to: Alcina MMB Morais, Escola Superior de Biotecnologia, Universidade Católica Portuguesa, Rua Dr António Bernardino de Almeida, 4200-072 Porto, Portugal

E-mail: amorais@esb.ucp.pt 
Apple browning is the result of enzymatic oxidation of endogenous phenols into quinones, which polymerise into brown products. ${ }^{12}$ Browning was, in most cases, reported to increase during storage. ${ }^{9}$ Many authors have sought to establish a relationship between the degree of browning and the phenolic content and/or enzymatic activity of apples. $3,4,9,13$ Nevertheless, results are divergent as to which of the two factors, the enzyme or the substrate, plays the decisive role in the overall phenomenon of enzymatic browning. $^{3,8,12,14}$ Thus it was found that browning was mainly related to PPO activity ${ }^{9}$ or to phenolic content. $^{15}$ A study carried out on 22 New Zealand varieties concluded that neither of these parameters correlated well with the extent of browning. ${ }^{4}$ A similar conclusion was obtained with seven US cultivars, although the authors ${ }^{3}$ indicated that four cultivars ('Classic Delicious', 'RI Greening', 'Cortland' and 'McIntosh') showed a good correlation between degree of browning and enzyme activity, while the other three ('Empire', 'Golden Delicious' and 'Rome') displayed a good correlation between degree of browning and total phenolic content. The phenolic compounds and PPO activity were studied in the fruits of 11 apple cultivars before and after bruising in relation to their susceptibility to browning. ${ }^{13}$ It appeared that all the phenols were affected by browning, but neither the initial nor final phenolic contents correlated well with browning susceptibility estimated by the measurement of soluble $\left(A_{400}\right)$ or insoluble $\left(L^{*}\right)$ brown pigments, and the same held for PPO activity.

The aim of this work was to follow the PPO activity and phenolic content of minimally processed apple during cold storage and to establish potential relationships with enzymatic browning.

\section{EXPERIMENTAL \\ Plant material}

Apples (cv 'Jonagored') were grown at Estação Regional de Fruticultura e Vitivinicultura, Quinta de Sergude, Felgueiras, Portugal. The harvest date was 25 September 1995. The fruits were stored in air at $4{ }^{\circ} \mathrm{C}$ for 1-3 months until used in the experiments.

\section{Treatment and storage conditions}

Apples stored under refrigeration were transported weekly to the laboratory in Porto. The apples for each experiment were initially washed in chlorinated water (150 ppm of active chlorine for $5 \mathrm{~min})^{16}$ to eliminate surface contamination. After peeling and coring, each apple was cut into approximately $1.5 \mathrm{~cm}$ cubes and then randomly selected for different experiments. The apple samples were stored in open glass jars at $4^{\circ} \mathrm{C}$ for 7 days in the dark. Samples were evaluated in terms of several physicochemical parameters after various times of storage.

\section{Physicochemical evaluation}

Three replicates of 30 apple cubes were used per treatment.

\section{Colour assessment}

Cut apple surface colour was measured at the surface of each of the 30 apple cubes with a hand-held tristimulus reflectance colorimeter (Minolta CR-300, Minolta Corp, Ramsey, NJ, USA). Colour was recorded using a $\mathrm{CIE} L^{*}, a^{*}, b^{*}$ uniform colour space, where $L^{*}$ indicates lightness, $a^{*}$ indicates chromaticity on a green $(-)$ to red $(+)$ axis and $b^{*}$ indicates chromaticity on a blue $(-)$ to yellow $(+)$ axis. Numerical values of $a^{*}$ and $b^{*}$ were converted into hue angle $\left(H^{\circ}=\tan ^{-1}\left(b^{*} / a^{*}\right)\right)$ and chroma $\left(\right.$ chroma $\left.=\left(a^{*^{2}}+b^{*^{2}}\right)^{1 / 2}\right) \cdot{ }^{17}$

\section{Assay for PPO activity}

Enzymatic activity was assayed by measuring the rate of increase in absorbance at $420 \mathrm{~nm}$ and $25^{\circ} \mathrm{C}$ in a Perkin-Elmer Lambda 15 UV/VIS spectrophotometer (Shimadzu Corp, Tokyo, Japan). The reaction mixture contained $3.0 \mathrm{ml}$ of $0.6 \mathrm{M}$ catechol solution, freshly prepared in $0.05 \mathrm{M}$ sodium phosphate buffer at $\mathrm{pH}$ 6.5, and a fixed quantity of enzyme. The reference cuvette contained only the substrate solution. The reaction was conducted at $25^{\circ} \mathrm{C}$. The straight line section of the activity curve as a function of time was used to determine the enzyme activity $\left(\mathrm{U} \mu \mathrm{g}^{-1}\right.$ protein $\left.\mathrm{min}^{-1}\right)$. The unit for enzymatic activity was defined as a change of 0.001 in the absorbance value under the conditions of the assay. ${ }^{18}$ All determinations were performed in triplicate.

\section{Total phenolic content}

Each replicate of 30 apple cubes was crushed and homogenised with water, then centrifuged at $170 \times g$ for $10 \mathrm{~min}$ at $4^{\circ} \mathrm{C}$. Total phenolic content was measured using Folin-Ciocalteau reagent. ${ }^{19,20}$ Aliquots $(0.50 \mathrm{ml})$ of the clear apple juice were diluted in $9.5 \mathrm{ml}$ of deionised water, and $5 \mathrm{ml}$ of diluted FolinCiocalteau reagent ( $1 \mathrm{ml}$ plus $9 \mathrm{ml}$ of deionised water) was added to $1 \mathrm{ml}$ of the resulting solution. Between $30 \mathrm{~s}$ and $8 \mathrm{~min}$ after the addition of Folin-Ciocalteau reagent, $4 \mathrm{ml}$ of sodium carbonate solution $(0.075 \mathrm{~g}$ sodium carbonate $\mathrm{ml}^{-1}$ ) was added. After 1 hour at $30^{\circ} \mathrm{C}$ and $1 \mathrm{~h}$ at $0^{\circ} \mathrm{C}$ the absorbance of the solution was measured at $760 \mathrm{~nm}$. Dopamine was used to obtain the standard curve (0.5-5.0 $\mu \mathrm{g}$ dopamine $\mathrm{ml}^{-1}$ ), and the concentration of phenols was calculated directly from that curve, since the standard and samples were treated identically. Total phenols were expressed as $\mu \mathrm{g}$ dopamine $\mathrm{kg}^{-1}$ fruit fresh weight.

\section{Browning index (BI)}

Frozen apple $(50 \mathrm{~g})$ from each replicate of 10 fruits was homogenised in a laboratory blender for $2 \mathrm{~min}$. The homogenates were centrifuged at $800 \times g$ for $25 \mathrm{~min}$ at $4{ }^{\circ} \mathrm{C}$ and filtered through Whatman No 4 filter paper, 
then the absorbance of the resulting clear juice was measured immediately at $420 \mathrm{~nm}$ to determine BI. Higher values of absorbance at $420 \mathrm{~nm}$ correspond to higher browning of the tissue. ${ }^{21}$

\section{Protein content}

The protein content was determined in all preparations by the colorimetric method described by Bradford. $^{22}$ The values were obtained by graphic interpolation on a calibration standard curve with bovine serum albumin (BSA) at $595 \mathrm{~nm}$.

\section{Polyacrylamide gel electrophoresis}

Separation of apple PPO into multiple forms was attempted by a modification of the polyacrylamide gel electrophoresis (PAGE) procedure described by Davis. ${ }^{23}$ A BioRad Miniprotean II dual slab cell (BioRad, Richmund, CA, USA) was used for the electrophoresis. Bisacrylamide gels at $75 \mathrm{~g} \mathrm{l}^{-1}$ were used, according to Laemmli, ${ }^{24}$ but under native conditions (ie without sodium dodecyl sulphate (SDS)). Gels were incubated for $1 \mathrm{~h}$ in an aqueous solution containing $400 \mathrm{ml}^{-1}$ methanol, $100 \mathrm{ml}^{-1}$ acetic acid and $1 \mathrm{~g} \mathrm{l}^{-1}$ coomassie brilliant blue R-250 using a shaker (Rotator Heidolph, Schwadach, Germany). The gels were then destained in a solution identical to the one described above, but without the stain, to reveal the protein bands. The gels were dried under vacuum in a BioRad model 583 gel dryer for $2 \mathrm{~h}$ at $80^{\circ} \mathrm{C}$ and the relative mobility $(\mathrm{RM})$ values were determined.

\section{Statistical analysis}

The SAS computer system package ${ }^{25}$ was used for analysis of the data. Statistical significance was assessed by two-way analysis of variance (the source of variation was storage time). The overall least significant difference (LSD; $P=0.05$ ) was calculated and used to detect significant differences among storage times. Relationships among measurement variables were studied using standard correlation, $R$ being the correlation factor.

\section{RESULTS AND DISCUSSION \\ Colour changes}

The apple cubes underwent colour changes during the first few days of storage, as can be observed by the increase in $a^{*}$ value and the decrease in hue angle (Figs 1 and 2). Also, the $L^{*}$ value decreased (loss of lightness) and the chroma value increased, but at a later stage of storage (Figs 3 and 4). Chroma values followed the same profile with time as $b^{*}$ values (data not shown). An increase in saturation (chroma value) indicates an increase in overall pigmentation.

The observed changes in colour parameters were found to be highly correlated with storage time, especially the decreases in $L^{*}$ value $\left(R^{2}=0.98\right)$ and hue angle $\left(R^{2}=0.99\right)$.

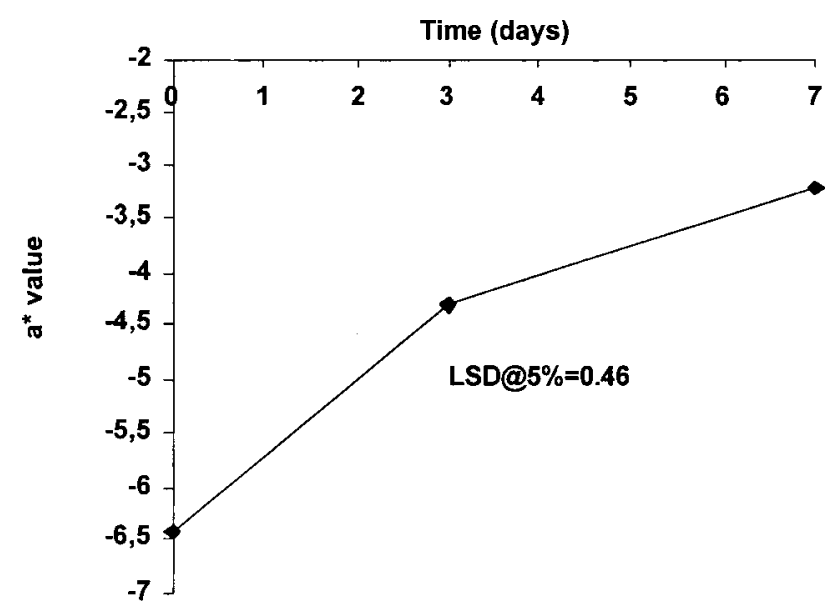

Figure 1. $a^{*}$ value of minimally processed 'Jonagored' apple during storage at $4^{\circ} \mathrm{C}$ in the dark.

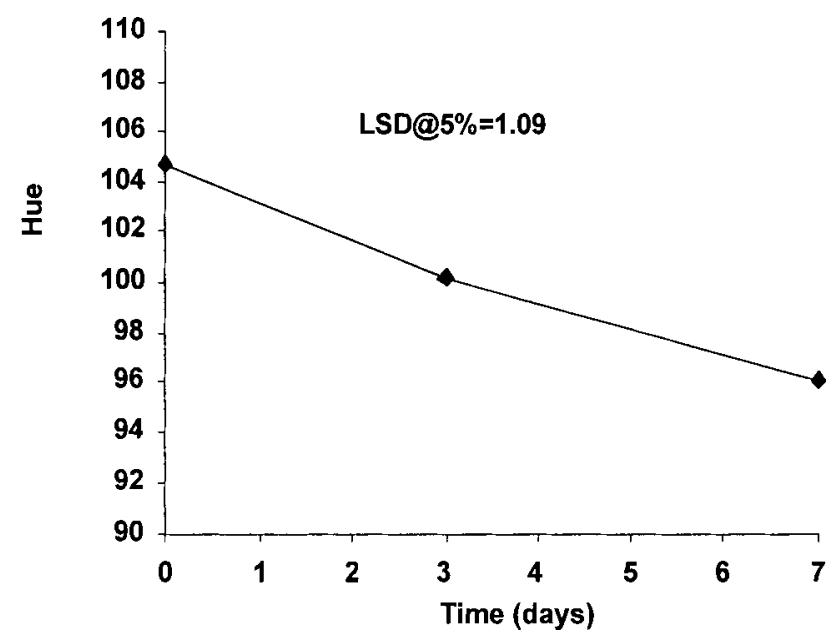

Figure 2. Hue angle of minimally processed 'Jonagored' apple during storage at $4^{\circ} \mathrm{C}$ in the dark.

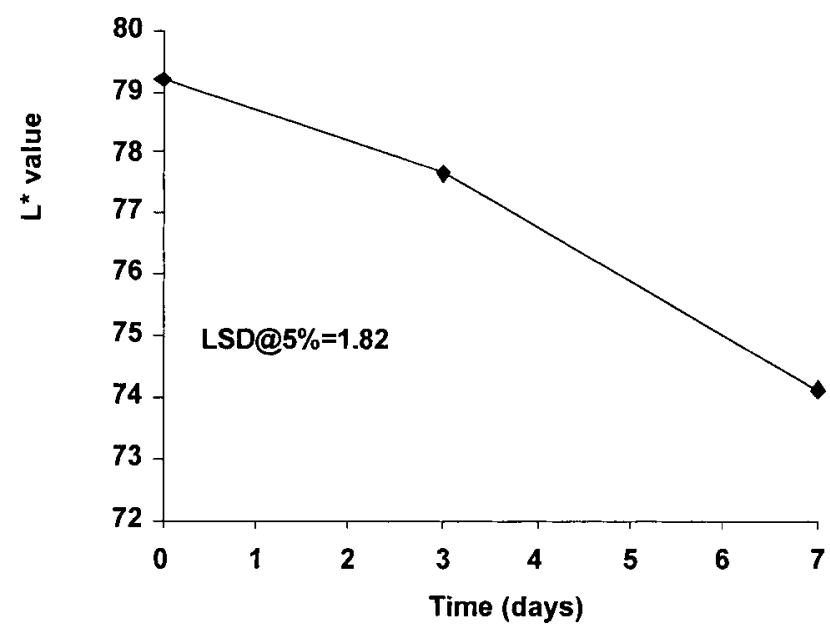

Figure 3. $L^{*}$ value of minimally processed 'Jonagored' apple during storage at $4^{\circ} \mathrm{C}$ in the dark.

\section{Polyphenoloxidase activity}

The PPO activity (U $\mu \mathrm{g}^{-1}$ protein $\mathrm{min}^{-1}$ ) of 'Jonagored' apple cubes showed a significant increase 


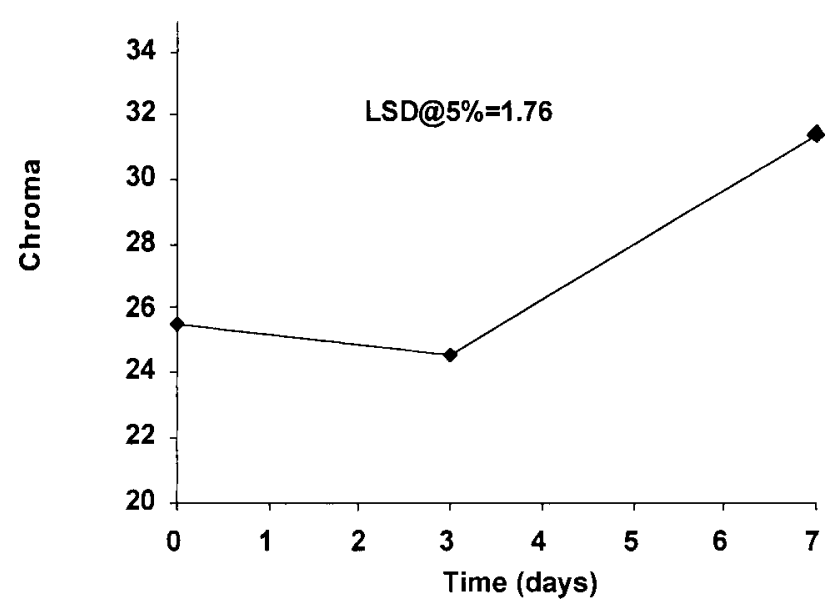

Figure 4. Chroma value of minimally processed 'Jonagored' apple during storage at $4^{\circ} \mathrm{C}$ in the dark.

$(P<0.05)$ between days 0 and 3 and was constant thereafter (Fig 5). This contrasts with the colour data which showed a large increase between days 3 and 7 .

When evaluating PPO activity expressed as $\mathrm{Ug}^{-1}$ fruit fresh weight $\min ^{-1}$, a decrease was observed between days 3 and 7 of storage (Fig 6), which did not follow the tendency observed when PPO activity was expressed as $\mathrm{U}_{\mu \mathrm{g}}{ }^{-1}$ protein $\mathrm{min}^{-1}$. This decrease was due to the decrease in protein content during storage (data not shown).

Data available in the literature concerning PPO stability during storage deal almost exclusively with whole fruits. Vámos-Vigyázó et $a l^{26}$ reported that the PPO activity (U min ${ }^{-1} \mathrm{~g}^{-1}$ fruit fresh weight) of 'Jonathan' apple remained constant during 3 months of storage at $4{ }^{\circ} \mathrm{C}$ and decreased steadily afterwards. Coseteng and $\mathrm{Lee}^{3}$ also reported that the PPO activity (U min ${ }^{-1} \mathrm{ml}^{-1}$ extract) of ' $\mathrm{RI}$ Greening' and 'Cortland' varieties of apple remained relatively constant during 3 months of storage at $0^{\circ} \mathrm{C}$.

Few studies were found in the literature regarding the influence of minimal processing operations on

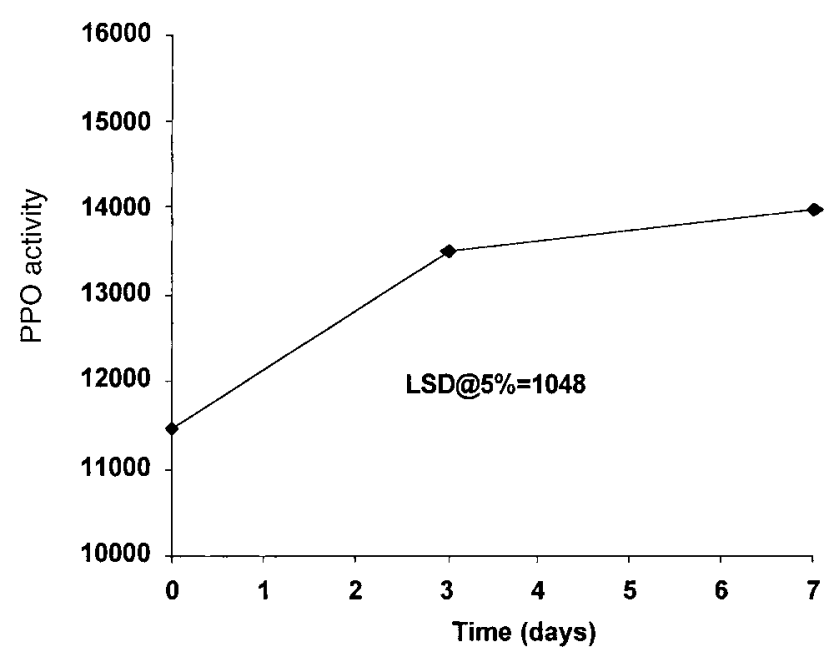

Figure 5. PPO activity $\left(\mathrm{U}_{\mu \mathrm{g}}{ }^{-1}\right.$ protein $\left.\mathrm{min}^{-1}\right)$ of minimally processed 'Jonagored' apple during storage at $4^{\circ} \mathrm{C}$ in the dark.

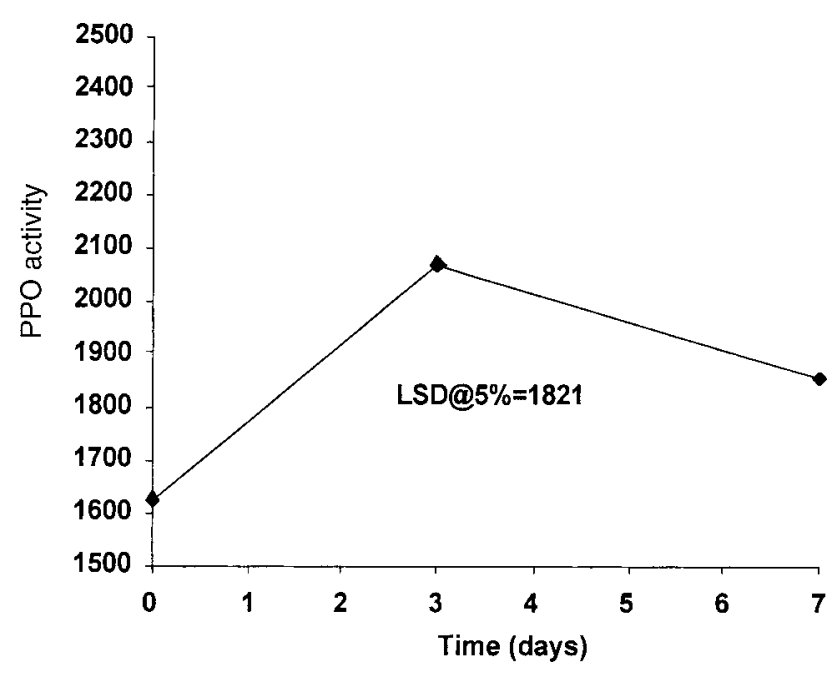

Figure 6. PPO activity $\left(\mathrm{Ug}^{-1}\right.$ fruit fresh weight $\left.\mathrm{min}^{-1}\right)$ of minimally processed 'Jonagored' apple during storage at $4^{\circ} \mathrm{C}$ in the dark.

PPO activity. Buescher et $a l^{27}$ reported that PPO activity' increaseed after snap bean pods were broken and that the activity of phenolases was closely associated with the development of browning. Couture et $a l^{28}$ evaluated the physiological changes of minimally processed lettuce during storage and reported no significant changes in PPO activity $\left(\mu \mathrm{molg}^{-1}\right.$ fresh weight $\left.\min ^{-1}\right)$ during 4 days at $2.5^{\circ} \mathrm{C}$. Ke and Saltveit ${ }^{29}$ also reported that wounding (by cutting the leaves or puncturing the tissue) of iceberg lettuce did not enhance PPO activity $\left(\mu \mathrm{molg}^{-1}\right.$ fresh weight $\min ^{-1}$ ).

\section{Phenolic content}

The total phenolic content of 'Jonagored' apple cubes was about $12700 \mu \mathrm{g} \mathrm{kg}^{-1}$ fresh apple. Similar results were obtained by Cilliers et al, ${ }^{30}$ who studied 'Jonathan' apple $\left(12690 \mu \mathrm{g} \mathrm{kg}^{-1}\right)$. Coseteng and Lee ${ }^{3}$ studied nine varieties of apple ('Tydeman Early', 'Paulared', 'Classic Delicious', 'Golden Delicious', 'McIntosh', 'Cortland', 'RI Greening', 'Empire' and 'Rome') and found that almost all of them had levels of phenolics ranging between 15000 and $20000 \mu \mathrm{g} \mathrm{kg}^{-1}$. Vámos-Vigyázó et $a l^{26}$ also reported similar values. In their characterisation of 'Anna' apple, Trejo-Gonzaléz and Soto-Valdez ${ }^{31}$ reported a phenolic content of about $11600 \mu \mathrm{g} \mathrm{kg}^{-1}$. Barrett et al reported that the concentration of total phenols in 'Delicious' apples was fairly stable during storage. They did not find significant differences in total phenol concentration between apples analysed immediately after harvest and those held in air. It seems that the phenolic content is not substantially different from one apple variety to another.

There was a significant increase in the total phenolic content of 'Jonagored' apple cubes between days 0 and 3 , followed by a decrease (Fig 7), results that are in agreement with other studies which concluded that individual phenolic compounds of whole fruits might vary in their browning rates. ${ }^{8,9}$ 


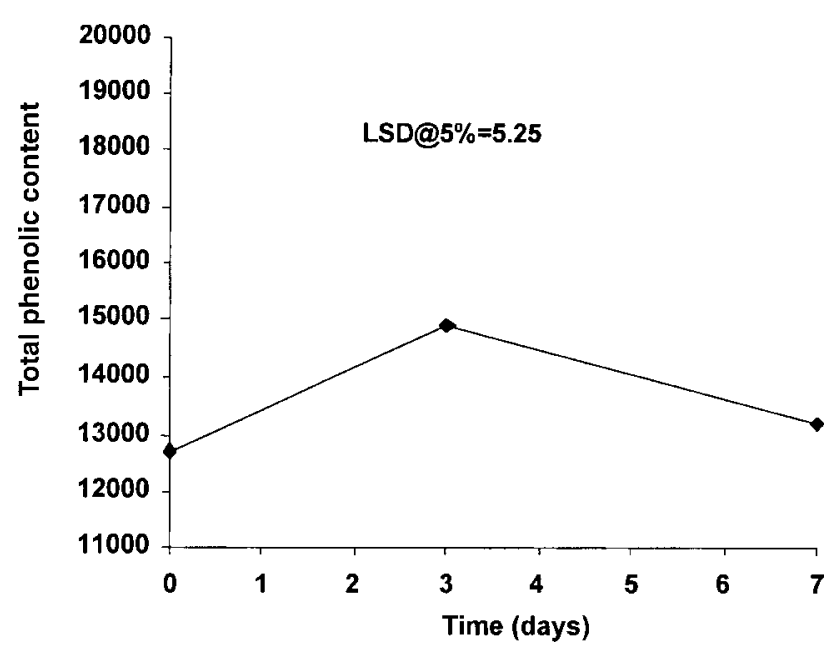

Figure 7. Total phenolic content ( $\mu \mathrm{g}$ dopamine $\mathrm{kg}^{-1}$ ) of minimally processed 'Jonagored' apple during storage at $4^{\circ} \mathrm{C}$ in the dark.

Little information exists concerning the influence of minimal processing operations on the phenolic content of commodities. Buescher et $a l^{27}$ reported that phenolic content increased after snap beans pods were broken. Ke and Saltveit ${ }^{29}$ reported that wounding (by cutting the leaves or puncturing the tissue) of iceberg lettuce caused an increase in total soluble phenolic content, but those compounds were oxidised into brown substances within minutes by PPO. Howard and Griffin ${ }^{32}$ reported an increase in total phenols of minimally processed carrot sticks and associated this with a wound-induced increase in PAL (phenylalanine-ammonia-lyase). When evaluating the shelf-life of minimally processed lettuce, Couture et $a l^{28}$ reported an increase in phenolic content during storage for 3 days at $2.5^{\circ} \mathrm{C}$. Lattanzio et $a l^{6}$ found that the phenolic content of artichoke heads was generally higher in mechanically damaged samples than in intact ones, although they had expected a reduction in phenolic content due to oxidative phenomena.

\section{Browning index (BI)}

The browning of 'Jonagored' apple, measured as the browning index (BI), increased significantly between days 0 and 3 of storage and remained approximately constant thereafter (Fig 8).

Couture et $a l^{28}$ studied the shelf-life of minimally processed lettuce and reported an increase in browning intensity $\left(A_{340}\right)$ during 5 days of storage at $2.5^{\circ} \mathrm{C}$. Since the concentration of total phenolic compounds was constant in the present study (Fig 7), the increase in BI suggests an increase in the proportion of oxidised phenols during apple storage. Coseteng and $\mathrm{Lee}^{3}$ reported very small changes in browning $\left(A_{440}\right)$ of apples (cvs 'RI Greening', 'Golden Delicious', 'McIntosh' and 'Empire') during 80 days of storage at $1{ }^{\circ} \mathrm{C}$.

\section{Electrophoretic data}

No changes were observed in the electrophoretic

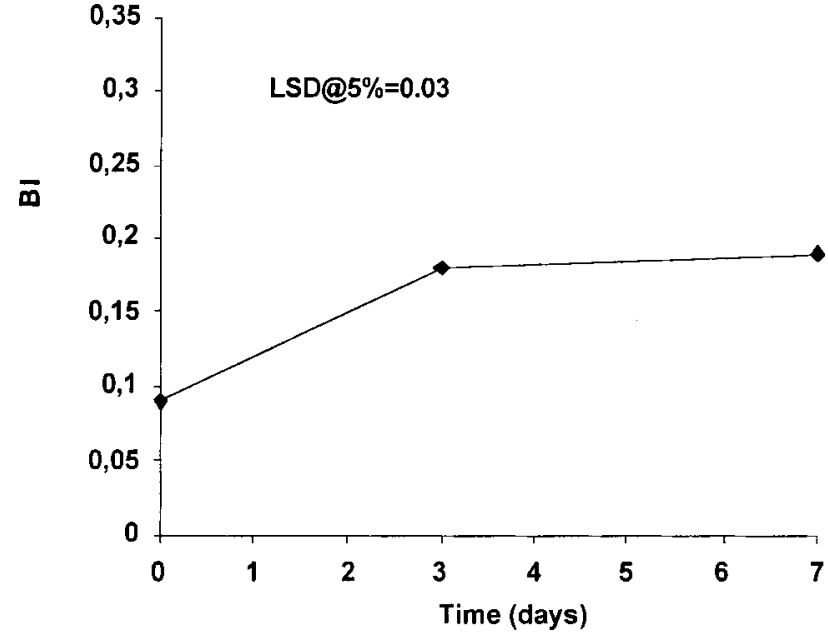

Figure 8. Browning index $(\mathrm{BI})$ of minimally processed 'Jonagored' apple during storage at $4^{\circ} \mathrm{C}$ in the dark.

pattern of PPO extracted from 'Jonagored' apple stored for 7 days at $4^{\circ} \mathrm{C}$. Only one band was detected with an RM of 0.45 towards the anode (data not shown).

Relationships between colour parameters ( $L^{*}, a^{*}, b^{*}$, hue and chroma), BI, total phenolic content and PPO activity

Overall, moderate to high correlations were found between some colour parameters and PPO activity $\left(\mathrm{U}_{\mu \mathrm{g}}{ }^{-1}\right.$ protein $\left.\min ^{-1}\right): R^{2}=0.71$ for $L^{*}$ value, $R^{2}=0.97$ for $a^{*}$ value (Table 1 ).

A high correlation $\left(R^{2}=0.99\right)$ was obtained when PPO activity was plotted against BI: the higher the PPO activity, the higher the BI (Table 1). Moderate to high correlations were obtained when PPO activity was plotted against $L^{*}, a^{*}$ and hue values; the PPO activity seemed to follow the colour changes of the apple cubes (Table 1).

Coseteng and Lee ${ }^{3}$ compared the degree of browning $\left(A_{440}\right)$ of seven apple cultivars with their respective enzyme activities and phenol levels and found that the correlations established were cultivar-dependent. They obtained a direct correlation between PPO activity and degree of browning $\left(R^{2}=0.83\right)$ for 'Classic

\begin{tabular}{lr} 
Table 1. Correlations $\left(R^{2}\right)$ & between \\
PPO activity $\left(\mathrm{U}^{-1}\right.$ protein $\left.\mathrm{min}^{-1}\right)$ & Control \\
and several parameters of minimally \\
processed 'Jonagored' during storage \\
\hline Quality parameter & \\
\hline Colour & \\
$L^{*}$ value & 0.71 \\
$a^{*}$ value & 0.97 \\
$b^{*}$ value & 0.35 \\
Hue angle & 0.90 \\
Chroma & 0.29 \\
Browning index & 0.99 \\
\hline$R^{2}$ at level $P=0.05$. &
\end{tabular}


Delicious', 'RI Greening', 'Cortland' and 'McIntosh'. On the other hand, a high correlation was found between total phenolic content and degree of browning $\left(R^{2}=0.99\right)$ for 'Empire', 'Golden Delicious' and 'Rome'.

Lee $e a^{33}$ also reported that the degree of browning of peach cultivars was correlated with their PPO activity: peach cultivars having higher PPO activity showed a higher rate of browning; conversely, peaches lower in PPO activity showed a lower rate of browning.

No correlation was found when phenolic content was plotted against $L^{*}$ value and hue angle. Very weak correlations were obtained between phenolic content and $a^{*}, b^{*}$ and chroma values (Table 2). No correlation was found either when the BI of 'Jonagored' apple cubes was plotted against total phenolic content (Table 2). Results reported in the literature in this respect are somewhat contradictory. Some authors who worked with apples and peaches noticed an increase in degree of browning with an increase in phenolic content and suggested that BI is determined by the amount of phenolic compounds present in the fruit. ${ }^{3,33}$ However, Amiot $e t a l^{13}$ found that the degree of browning measured by absorbance at $400 \mathrm{~nm}$ (soluble pigments) and lightness $L^{*}$ (insoluble pigments) was closely related to the amount of phenols degraded. In a study with artichoke heads, Lattanzio et $a l^{6}$ reported that changes in the levels of phenolic substrates of artichoke heads during storage do not run parallel to the appearance and intensity of browning. Lee $e t a l^{33}$ reported that the degree of browning of peach cultivars was correlated with their phenolic content $\left(R^{2}=0.67\right)$. Goupy et $a l^{34}$ reported that the degree of browning of apple was related to the amounts and types of degraded phenols. They stated that, owing to coupled oxidation, the oxidised amounts within one type could be increased or decreased by increasing amounts in the other phenols. Therefore, for equivalent total phenolic contents, the resulting pigments could vary both quantitatively and qualitatively, leading to widely different values of $L^{*}$, $a^{*}$ and $b^{*}$.

Results reported in the literature attempting to

Table 2. Correlations $\left(R^{2}\right)$ between phenolic content and colour parameters, browning index and polyphenoloxidase (PPO) activity of minimally processed 'Jonagored' during storage

\begin{tabular}{lc}
\hline Quality parameter & Phenolic content \\
\hline Colour & _a $^{\text {a }}$ \\
$L^{*}$ value & 0.16 \\
$a^{*}$ value & 0.13 \\
$b^{*}$ value & $-^{a}$ \\
Hue angle & 0.17 \\
Chroma & 0.37 \\
Browning index & 0.29 \\
PPO activity & \\
\hline
\end{tabular}

${ }^{a}$ No correlation was found

$R^{2}$ at level $P=0.05$. establish relationships between browning and PPO activity and/or phenolic content are controversial. Vámos-Vigyázó $e t ~ a l,{ }^{9}$ in a study carried out with six apple cultivars, found a moderate linear correlation $\left(R^{2}=0.55\right)$ between enzymatic browning, measured as $A_{540}$, and PPO activity, while there was no correlation between enzymatic browning and phenolic content $\left(R^{2}=0.18\right)$. In a subsequent study ${ }^{26}$ the same authors reported that browning, measured as absorbance at $540 \mathrm{~nm}$, of 'Jonathan' and 'Starking' apples depended significantly on both PPO activity and $o$-dihydroxyphenol levels. Ma et $\mathrm{al}^{35}$ reported a negative correlation between darkening of sweet potatoes, evaluated visually by an expert panel, and phenolic content, indicating that the substrate level might be the major factor contributing to darkening.

A moderately negative correlation $\left(R^{2}=0.63\right)$ was found when $L^{*}$ value was plotted against BI (Table 3 ). This negative correlation showed that the higher the degree of browning encountered, the lower the $L^{*}$ value of the samples. Several studies reported in the literature indicate that apples with low lightness (lower $L^{*}$ value) are characterised by higher BI. ${ }^{8,13}$ High correlations were obtained between $\mathrm{BI}$ and $a^{*}$ and hue values, but weak correlations were obtained when BI was plotted against $b^{*}$ and chroma values (Table 3 ), as observed for the correlations between these colour parameters and PPO activity (Table 1).

\section{CONCLUSIONS}

Refrigerated storage of minimally processed 'Jonagored' apple for 7 days at $4{ }^{\circ} \mathrm{C}$ seemed to cause an increase in PPO activity from 11441 to $13968 \mathrm{U} \mathrm{\mu g}^{-1}$ protein $\mathrm{min}^{-1}$. This increase was found to be highly correlated with storage time $\left(R^{2}=0.82\right)$. The total phenolic content of 'Jonagored' apple cubes was around $12700 \mu \mathrm{g} \mathrm{kg}^{-1}$ fresh apple and did not change during storage.

Colour degradation of apple cubes during storage, as indicated by changes in colour parameters, was found to be quite well correlated with PPO activity $\left(R^{2}\right.$ between 0.71 and 0.97), except for $b^{*}$ and chroma values.

Browning of 'Jonagored' apple cubes during storage was found to be well correlated with PPO activity $\left(R^{2}=0.87\right)$. No correlation was found between $\mathrm{BI}$ and total phenolic content. The predominance of PPO

Table 3. Correlations $\left(R^{2}\right)$ between browning index and colour parameters of minimally processed 'Jonagored' during storage

\begin{tabular}{lc}
\hline Colour parameter & Browning index \\
\hline$L^{*}$ value & 0.63 \\
$a^{*}$ value & 0.94 \\
$b^{*}$ value & 0.27 \\
Hue angle & 0.84 \\
Chroma & 0.22 \\
\hline
\end{tabular}

$R^{2}$ at level $P=0.05$. 
activity in the phenomenon of enzymatic browning of 'Jonagored' apple cubes seems to be evident in relation to the role of phenolic content.

\section{ACKNOWLEDGEMENTS}

This research was funded by a JNICT scholarship (Praxis XXI BD 5365/95). The authors gratefully acknowledge the collaboration of Estação Regional de Fruticultura e Vitivincultura, Quinta de Sergude, Felgueiras, Portugal.

\section{REFERENCES}

1 Barrett DM, Lee CY and Liu FW, Changes in 'Delicious' apple browning and softening during controlled atmosphere storage. f Food Qual 14:443-445 (1991).

2 Zocca A and Ryugo K, Changes in polyphenoloxidase activity and substrate levels in maturing 'Golden Delicious' apple and other cultivars. HortScience 10:586-587 (1975).

3 Coseteng MY and Lee CY, Changes in apple polyphenoloxidase and polyphenol concentrations in relation to degree of browning. F Food Sci 52:985-989 (1987).

4 Klein BP, Relationship of harvest date, storage conditions, and fruit characteristics to bruise susceptibility of apple. $\mathcal{F} \mathrm{Am}$ Soc Hort Sci 112:113-116 (1987).

5 Brecht JK, Physiology of lightly processed fruits and vegetables. HortScience 30:18-21 (1995).

6 Lattanzio V, Cardinali A and Palmieri S, The role of phenolics in the postharvest physiology of fruits and vegetables: browning reactions and fungal diseases. Ital f Food Sci 1:3-22 (1994).

7 Rolle RS and Chism GW, Physiological consequences of minimally processed fruits and vegetables. I Food Qual 10:157-177 (1987).

8 Burda S, Oleszek W and Lee CY, Phenolic compounds and their changes in apples during maturation and cold storage. $7 \mathrm{Sci}$ Food Agric 38:945-948 (1990).

9 Vámos-Vigyázó L, Gajzágó I, Nádudvari-Márkus V and Mihályi $\mathrm{K}$, Studies into the enzymic browning and the polyphenolpolyphenol oxidase complex of apple cultivars. Confructa 21:24-35 (1976).

10 Kahn V, Effect of proteins, protein hydrolyzates and amino acids on $o$-dihydroxyphenolase activity of polyphenol oxidase of mushroom, avocado and banana. f Food Sci 50:111-115 (1985).

11 Whitaker JR, Effect of substrate concentration on rates of enzyme-catalyzed reactions, in Principles of Enzymology. Marcel Dekker, New York, pp 167 (1994).

12 Amiot MJ, Tacchini M, Aubert S and Nicolas J, Phenolic composition and browning susceptibility of various apple cultivars at maturity. F Food Sci 57:958-962 (1992).

13 Amiot MJ, Aubert S and Nicolas J, Phenolic composition and browning susceptibility of various apple and pear cultivars at maturity. Acta Hort 343:67-71 (1993).

14 Martinez MV and Whitaker JR, The biochemistry and control of enzymatic browning. Trends Food Sci Technol 6:195-200 (1995).

15 Walker JR, Studies on the enzymic browning of apple fruit. $N Z \mathcal{F}$ Food Sci 5:316 (1962).

16 Wardowski WF and Brown GE, Postharvest decay control recommendations for Florida citrus fruit. Circular 952,
Institute of Food and Agricultural Sciences. University of Florida, Gainesville, FL (1991).

17 Francis FJ, Colour quality evaluation of horticultural crops. HortScience 15:58-59 (1980).

18 Galeazzi MAM, Sagarbieri VCJ and Constantidines SM, Isolation, purification and physicochemical characterization of polyphenoloxidase from a dwarf variety of banana (Musa cavendishii, L). F Food Sci 46:150-155 (1981).

19 Folin D and Ciocalteau V, On tyrosine and tryptophan determinations in proteins. F Biol Chem 73:627-650 (1927).

20 Singleton VL and Rossi Jr JA, Colorimetry of total phenolics with phosphomolybdic-phosphotungstic acid reagents. $A m \mathcal{F}$ Enol Vitic 16:144-158 (1965).

21 Wrolstad RE, Color and pigment analyses in fruit products. Station Bull No 624, Agricultural Experiment Station, Oregon State University, Corvallis, OR (1976).

22 Bradford MM, A rapid and sensitive method for the quantification of microgram quantities of protein utilizing the principle of protein binding. Anal Biochem 72:248-254 (1976).

23 Davis BJ, Disk electrophoresis. 2. Method and application to human serum proteins. Ann NY Acad Sci 121:404-410 (1964).

24 Laemmli UK, Cleavage of structural proteins during the assembly of the head of bacteriophage T4. Nature 227:680 (1970).

25 SAS, SAS User's Guide: Statistics. SAS Institute, Cary, NC (1982).

26 Vámos-Vigyázó L, Gajzágó I, Nadudvari-Markus V, HámoriSzabó J and Sass P, Changes in the polyphenol-polyphenol oxidase complex of apples during ripening and storage. Chem Mikrobiol Technol Lebensm 9:37-47 (1985).

27 Buescher RW, Reitmeier C and Sistrunk WA, Association of phenylalanine ammonia lyase, catecholase, peroxidase and total phenolic content with brown-end discoloration of snap bean pods. HortScience 9:585 (1974).

28 Couture R, Cantwell MI, Ke D and Saltveit Jr ME, Physiological attributes related to quality attributes and storage life of minimally processed lettuce. HortScience 28:723-725 (1993).

$29 \mathrm{Ke} \mathrm{D}$ and Saltveit ME, Wound induced ethylene production, phenolic metabolism and susceptibility to russet spotting in iceberg lettuce. Physiol Plant 76:412-414 (1989).

30 Cilliers JJL, Singleton VL and Lamuela-Raventos RM, Total polyphenols in apples and ciders; correlation with chlorogenic acid. F Food Sci 55:1458-1459 (1990).

31 Trejo-Gonzaléz A and Soto-Valdez H, Partial characterization of polyphenoloxidase extracted from 'Anna' apple. 7 Am Soc Hort Sci 116:672-675 (1991).

32 Howard LR and Griffin LE, Lignin formation and surface discoloration of minimally processed carrot sticks. F Food Sci 58:1065-1067 (1993).

33 Lee CY, Kagan V, Jaworski AW and Brown SK, Enzymatic browning in relation to phenolic compounds and polyphenoloxidase activity among various peach cultivars. $\mathcal{f}$ Agric Food Chem 38:99-101 (1990).

34 Goupy P, Amiot MJ, Richard-Forget F, Duprat F, Aubert S and Nicolas J, Enzymatic browning of model solutions and apple phenolic substrates by apple polyphenoloxidase. I Food Sci 60:497-501 (1995).

35 Ma S, Silva JL, Hearnsberger JO and Garner Jr JO, Prevention of enzymatic darkening in frozen sweet potatoes (Ipomoea batatas (L.) Lam.) by water blanching: relationship among darkening, phenols, and polyphenoloxidase activity. 7 Agric Food Chem 40:864-867 (1992). 